\title{
STRATEGI MANAJEMEN KRISIS HUMAS PLN UID JABAR DALAM MENANGANI BLACKOUT JARINGAN JAWA BAGIAN TENGAH
}

\author{
${ }^{1)}$ Siti Choerunnisa, ${ }^{2)}$ Aat Ruchiat Nugraha \\ ${ }^{1,2}$ Universitas Padjajaran \\ 1,2) Jl. Raya Bandung Sumedang KM.21, Sumedang, Jawa Barat 45363 - Indonesia \\ E-mail : ruchiat@unpad.ac.id
}

\begin{abstract}
ABSTRAK
Perusahaan Listrik Negara (PLN) sebagai satu-satunya perusahaan yang memasok listrik di Indonesia terus berupaya membangun untuk mewujudkan dapat mengalirkan energi listrik ke seluruh masyarakat dari kota hingga pelosok desa. Namun, pada bulan Agustus 2019, PT. PLN mengalami suatu peristiwa yang terjadi di luar dugaan semua pihak, yakni pemadaman serentak atau blackout yang diakibatkan oleh gangguan jaringan transmisi di jalur Ungaran-Pemalang. Fenomena padamnya aliran listrik berdampak sangat besar terhadap aspek objek vital di wilayah DKI Jakarta, Banten, Jawa Barat, serta sebagian Jawa Tengah dan mengakibatkan citra perusahaan menjadi buruk. Penelitian ini menggunakan pendekatan kualitatif dengan tujuan untuk mengetahui dan menjelaskan mengenai fenomena blackout yang dapat menurunkan citra negatif perusahaan di kalangan publiknya. Adapun metode pengumpulan data dilakukan dengan cara wawancara dan observasi dengan sejumlah pihak yang terlibat langsung pada penyelesaian blackout. Hasil penelitian menunjukkan bahwa perlu adanya peran serta dari bagian Humas untuk dapat memulihkan keadaan citra negatif mengenai dampak blackout yang ada di masyarakat melalui strategi manajemen krisis adaptif dalam dengan cara melakukan modifikasi operasional, kompromi, dan pengalihan fasilitas yang tertuang dalam program kerja humas. Simpulan penelitian menunjukkan bahwa penanganan strategi adaptif oleh bagian Humas PT. PLN dalam menghadapi situasi krisis blackout dapat tertangani dengan baik dan menghasilkan nilai yang cukup efektif dirasakan oleh publik.
\end{abstract}

Kata Kunci: Strategi, Manajemen Krisis, Humas, Citra, Blackout

\begin{abstract}
The National Electricity Company (PLN) as the only company that supplies electricity in Indonesia continues to develop to realize that it can deliver electricity to the entire community from cities to remote villages. However, in August 2019, PT. PLN experienced an event that occurred beyond the expectations of all parties, namely a simultaneous blackout or blackout caused by a disruption in the transmission network on the Ungaran-Pemalang line. The phenomenon of power outages has a tremendous impact on aspects of vital objects in the area of DKI Jakarta, Banten, West Java, and parts of Central Java and resulted in the company's image gets worse. This study uses a qualitative approach to find out and explain the blackout phenomenon that can reduce the company's negative image in public. The data collection method is done by interviewing and observing with several parties directly involved in the completion of the blackout. The results of the study indicate that there is a need for participation from the Public Relations department to be able to restore the negative image situation regarding the impact of blackouts in the community through adaptive crisis management strategies using operational modification, compromise, and transfer of facilities contained in the public relations work program. The conclusion of the research shows that the handling of adaptive strategies by the Public Relations of PT. PLN in dealing with a blackout crisis can be handled well and produce the value that is quite effectively felt by the public.
\end{abstract}

Keyword: Strategy, Crisis Management, Public Relations, PLN, Blackout. 


\section{PENDAHULUAN}

\section{A. Latar Belakang}

Listrik telah menjadi salah satu kebutuhan dasar yang sangat vital bagi kehidupan masyarakat di negara manapun di dunia, termasuk Indonesia. Dapat dibayangkan apabila hidup ini tanpa adanya aliran listrik. Saat ini, kebutuhan terhadap listrik disinyalir akan terus meningkat seiring dengan meningkatnya kebutuhan teknologi dan peradaban manusia. Keberadaan aliran listrik pada saat ini tidak hanya melingkupi kebutuhan rumah tangga, industri kecil menengah, namun lebih juga kepada aspek industri mega jaringan internet dan jaringan provider. Sudah dapat terbayangkan, saat ini di mana era pemenuhan kebutuhan masyarakat sudah terfasilitasi oleh aplikasi online yang menggunakan dasar aliran listrik. Apabila terjadi gangguan aliran listrik maka akan dapat mengganggu sistem komunikasi dan bisnis masyarakat yang terjadi selama ini dan akan terjadi domino effect pada aspek vital lainnya. Hal ini dapat terjadi dikarenakan semua hal saat ini telah terkoneksi dengan internet yang menggunakan sumber daya aliran listrik.

Saat ini pelanggan PLN telah mencapai 65 juta rumah tangga dan dipastikan akan terus bertambah ke depannya. Bisa dibayangkan betapa beratnya tantangan PLN untuk tidak hanya terus menyediakan listrik namun juga menjaga kualitas pelayanan. Mulai dari membangun infrastruktur kelistrikan, mengoperasikan 70\% pembangkit listrik dan nyaris $100 \%$ jaringan transmisi dan distribusi, menyalurkan kepada pelanggan di seluruh Indonesia. Bahkan, hingga seleksi dan negosiasi tarif listrik dengan produsen listrik swasta atau IPP (Independent Power Producer); semuanya dilakukan PLN sendiri. Dengan keadaan yang demikian membuat PLN masuk menjadi daftar perusahaan terbesar di dunia. Badan Usaha Milik Negara (BUMN) listrik ini masuk peringkat ke-477 di Global Fortune 500.

Tidak dapat dipungkiri PLN telah terbentuk menjadi suatu perusahaan dengan sistem jaringan raksasa yang dengan kedigdayaan sumber dayanya dapat menerangi Indonesia di setiap sudutnya, namun perusahaan dengan sistem secanggih dan sebesar ini pun masih dapat memiliki kegagalan teknis sekalipun. Seperti kasus yang baru saja menimpa PT PLN yakni Blackout Jaringan Jawa Bagain tengah yang melingkupi DKI Jakarta, Jawa Barat, Jawa tengah, Banten, dan sebagian Jawa Timur. Permasalahan teknis ini merupakan kejadian yang masif dan menjadi issue nasional dikarenakan jutaan warga dan aspek vital seperti transportasi dan telekomunikasi pun ikut terganggu. Hal ini merupakan awal sinyal terjadinya krisis bagi PLN. Sebab yang namanya krisis menurut Hardjana (1998) diartikan sebagai "bahaya yang datang secara berkala karena tidak pernah diambil tindakan yang memadai” (Partao, 2005).

Di sisi lain seiring dengan kemajuan teknologi media dengan jejaring internetnya, penyebaran suatu informasi akan mudah dan cepat tersebar apalagi mengenai informasi krisis dari suatu perusahaan yang bersifat skala nasional di suatu negara. Melalui derasnya arus informasi yang tersebar di media internet mengakibatkan tak 
terbendungnya komentar para warga di sosial media yang dapat terbaca oleh siapapun, kapanpun dan dimanapun, yang mengakibatkan citra perusahaan kerap memburuk seiring usahanya memperbaiki krisis. Untuk menenangkan riuhnya keadaan informasi yang tersebar di media sosial mengenai krisis di suatu perusahaan/lembaga, maka dibutuhkan seorang komunikator untuk memberikan penjelasan kepada publik yang sering kita kenal dengan peran Public Relations Officer.

Kondisi krisis komunikasi merupakan sebuah situasi yang dapat menimbulkan efek berkelanjutan operasional bisnis perusahaan pada masa yang akan datang, perlakuan dalam tiap tahapan krisis akan membantu meminimalisir reaksi negatif publik terhadap perusahaan (Koswara, 2014) yang dapat dilakukan oleh seorang public relations officer.

Public Relations memiliki strategi manajemen khusus untuk menangani krisis dalam perusahaannya, seperti pada krisis yang dialami PT. PLN (Persero) beberapa waktu lalu, yakni keadaan Black Out. Black Out merupakan suatu keadaan dimana hilangnya seluruh sumber tenaga pada suatu sistem tenaga listrik. Banyak faktor yang yang dapat mengakibatkan terjadinya Black Out. Ketidaksiapan pembangkit merupakan salah satu penyebab padam listrik dari sisi hulu. Pada sistem pembangkit interkoneksi atau pembangkit yang saling terhubung satu sama lain, jika ada salah satu pembangkit jatuh maka pembangkit yang lain harus memikul beban pembangkit yang jatuh tersebut. Lainnya, kehandalan sistem distribusi juga sama pentingnya dengan sistem pembangkitan. Gangguan pada jaringan distribusi dapat diakibatkan oleh faktor eksternal dan internal. Faktor Eksternal, antara lain ialah petir, pepohonan, binatang, dan penggalian. Sedangkan faktor internal dapat diakibatkan oleh kondisi komponen dan peralatan yang terpasang di jaringan yang kurang diperhatikan pemeliharaannya.

PT PLN (Persero) pun dalam hal ini tidak menutup semua kemungkinan terkait penyebab pemadaman listrik total pada Minggu (4/8) hingga Senin (5/8) lalu. Sebab itu PLN terus melakukan investigasi penyebab terjadinya peristiwa pemadaman listrik total atau black out di Jakarta, Banten, Jawa Barat dan sebagian Jawa Tengah tersebut. Pihaknya menduga peristiwa pemadaman listrik total separuh Jawa tersebut tidak hanya disebabkan adanya pohon tumbang di jalur transmisi Ungaran-Pemalang (Saluran Udara Tegangan Ekstra Tinggi/SUTET) $500 \mathrm{kV}$, namun ada penyebab lain yang saat ini masih terus dicari.

Sistem listrik di wilayah Jawa ini adalah sistem yang paling kuat di Indonesia. Sistem besar dengan interkoneksi yg masif memiliki sekitar 250 pembangkit listrik, 5.500 Gardu Induk Tegangan Ekstra Tinggi (GITET), 5.000 kilometer sirkuit transmisi $500 \mathrm{KV}$ dan $7.000 \mathrm{Km}$ transmisi $150 \mathrm{KV}$. Dari situ, bisa terlihat bahwa jaringan Jawa-Bali adalah sistem yang solid yang tak rentan terhadap blackout. Untuk mengetahui akar penyebab black out harus dilakukan investigasi yang melibatkan para ahli dari luar PLN. Semua data recorders dan data peralatan dikumpulkan dan dianalisis oleh tim penyelidik yang dibentuk. Maka dari itu sembari menunggu proses investigasi, di satu sisi masih 
banyak warga yang terus mengeluh, berbagai hujatan bermuncul di media sosial yang memperkeruh suasana perbaikan jaringan PLN, maka dari itu dibutuhkanlah peran Humas sebagai pendamai di tengah riuhnya emosi rakyat yang mengalami dampak kerugian dari kasus blackout ini serta tuntutan massif rakyat untuk PLN menyegerakan untuk menuntaskan pekerjaannya. Dari penjelasan di atas maka penulis tertarik untuk mengetahui mengenai tentang "Strategi Manajemen Krisis Humas PLN UID Jabar dalam Blackout Jaringan Jawa Bagian Tengah" yang memiliki nilai yang sangat unik dikarenakan menyangkut isu nasional dan merupakan lahan yang tepat dan krusial untuk tahu mengenai kontribusi peran serta humas di dalamnya.

\section{B. Tinjauan Teoritis}

1. Citra

Citra adalah kesan organisasi yang timbul dan berkembang dalam benak seseorang/publik akan pemahaman akan suatu kenyataan. Pemahaman itu sendiri muncul karena adanya suatu informasi (Prihatin \& Hidayat, 2011). Suatu perusahaan meyakini bahwa, citra yang positif merupakan suatu hal esensial, yang akan membawa kepada kesusksesan organisasi (Muchtar, 2016). Citra setiap perusahaan akan berbeda tergantung tolok ukur yang dibangun perusahaan terhadap masyarakat. Citra yang diharapkan oleh perusahaan belum tentu diinterpretasikan sama oleh stakeholder. Kekuatan stakeholder adalah mampu membentuk citra perusahaan terutama pelanggan. Pelanggan memiliki kemampuan untuk menilai baik buruknya perusahaan karena pelanggan yang merasakan secara langsung produk maupun jasa perusahaan (Negoro, 2014).

\section{Manajemen Krisis}

Setiap organisasi, besar atau kecil, memiliki peluang untuk terkena krisis. Krisis dapat terjadi karena kesalahan internal organisasi, seperti kesalahan prosedur, kelalaian organisasi dan tindakan oknum dalam organisasi yang tidak bertanggung jawab. Disamping itu, krisis juga dapat disebabkan oleh faktor ekternal seperti kondisi ekonomi dan politik, atau bencana alam (Suharyanti \& Sutawidjaya, 2012). (Kurhajcová, 2010) menjelaskan bahwa komunikasi krisis mempunyai area komunikasi spesifik, yang meliputi eksternal dan internal organisasi selama situasi krisis. Tujuan dari komunikasi krisis ini untuk menekan efek negatif yang terjadi dan menginformasikan kepada publik yang berada pada situasi krisis (Roro, Juneza, \& Purworini, 2016). 


\section{METODE}

Pendekatan yang digunakan dalam penelitian ini adalah pendekatan kualitatif atau juga disebut sebagai metode naturalistik dengan kondisi alamiah. Penelitian ini menggunakan pendekatan kualitatif, adalah penelitian yang bermaksud untuk memahami fenomena tentang apa yang dialami oleh subjek penelitian misalnya perilaku, persepsi, dan motivasi secara holistik, dan dengan cara deskripsi dalam bentuk kata-kata dan bahasa. Penelitian kualitatif bertujuan untuk menjelaskan fenomena dengan sedalam-dalamnya melalui pengumpulan data. Penelitian ini tidak mengutamakan besarnya populasi atau sampling. Penelitian ini menggunakan riset kualitatif, menggambarkan sebuah susunan perspektif atau informasi dari sebuah masalah. Tipe penelitian ini merupakan analisis kualitatif yang bersifat sistemis, transaksional atau subjektivis, analistis tapi tidak kaku seperti dalam analisis kuantitatif (Sucahya \& Surahman, 2017). Penelitian kualitatif lebih menekan pada persoalan kedalaman data bukan banyaknya data.

Teknik pengumpulan data yang dilakukan oleh penulis dengan cara melakukan wawancara kepada 3 Karyawan PLN yang menangani langsung mengenai kasus Blackout pada bulan Agustus silam. Yakni Manajer Komunikasi, Bapak Iwan Ridwan. Kemudian Asisten Manajer Divisi Humas, Ibu Eriga Wahyuwiranti, Serta Staff Divisi Humas, Bapak Fransiscus Anton.

\section{HASIL}

Pada pembahasan ini, penulis akan menganalisa sistem kendali krisis PT. PLN dalam upaya mengenali permasalahan untuk selanjutnya dapat mengembangkan strategi manajemen krisis yang tepat dengan beberapa pendekatan. Salah satunya akan penulis analisis berdasarkan model strategi manajemen krisis dari Rhenald Kasali (adaptasi model anatomi krisis Steven Fink), sebagai berikut;

\section{Tahap Prodomal}

Tahapan awal ini adalah saat bagaimana PLN telah mendeteksi tanda- tanda adanya suatu kesalahan pada sistem, namun ternyata tidak dapat disangka bahwasanya hal tersebut dapat mencuat menjadi sebuah krisis yang besar. Gejala awalnya sudah dapat dideteksi, namun tidak dapat terbendung dan teratasi sehingga terjadilah sebuah krisis. Awal mula terjadinya krisis adalah pada hari ahad, tanggal 04 Agustus 2019, dimana dirasa terjadi gangguan pada gas turbin 1 sampai 6 di Pembangkit Listrik Tenaga Uap Cilegon, Banten dan Pembangkit Listrik Tenaga Gas Turbin di Cilegon. Kemudian kembali terdeteksi gangguan lainnya pada pukul 11.45 detik 27 di transmisi sikuit satu di wilayah Utara yakni Saluran Udara Tegangan Ekstra Tinggi (SUTET) $500 \mathrm{Kv}$ pada jalur Ungaran-Pemalang. Disusul kembali oleh gangguan sirkuit kedua, akibatnya di menit 48 detik ke 11 menyebabkan jaringan Depok-Tasik alami gangguan.

Dua penyebab utama inilah yang menyebabkan krisis tak terbendung kemudian berlanjut kepada tahapan akut. saat ini pasokan listrik wilayah Jawa-Bali ditopang oleh dua 
jaringan yang berasal dari Utara dan Selatan. Sistem sebenarnya dapat dibendung, namun pada keadaan ini, saat sirkuit jaringan Utara sedang putus, PLN sedang melakukan pemeliharaan sirkuit yang berada di jaringan Selatan. Sehingga di dalam kondisi kesiapan daya tampung sirkuit yang terbatas, jaringan Selatan pun mendapatkan luapan daya listrik dari Timur akibat putusnya jaringan Utara. Luapan listrik tersebutlah yang membuat sistem jaringan listrik di wilayah Selatan ikut terganggu. Dikarenakan saat terjadi lepasnya dua sirkuit utara terlepas, kemudian daya dari Timur masuk ke jalur selatan, ini menyebabkan goncangan sistem yang mengganggu pembangkit. Karena itu, secara proteksi kesisteman wilayah Selatan ikut melepaskan tegangan hingga terjadinya putus jaringan total (blackout)

\section{Tahap Akut}

Pada tahapan ini, tuntutan dari berbagai kalangan sudah mulai berdatangan, para pelanggan sudah mulai merasakan dampaknya, yakni semua dimulai pada pukul 11.47. Akibatnya, Putusnya jaringan listrik di wilayah Selatan dan Utara ini membuat aliran listrik yang terpasok untuk ke Barat menjadi ikut tersendat. Lama-lama jaringan pembangkit listrik wilayah Barat pun daya listriknya semakin melemah dan ikut terlepas. Alhasil pada Ahad 04 Agustus 2019 yang lalu, sebagian daerah di wilayah Jawa listriknya padam. Hanya pembangkit wilayah yang menggunakan Jaringan Timur yang beroperasi normal.

Pembangkit yang terhubung secara sistem keamanan itu sudah melepaskan diri otomatis. Karena ini merupakan perlindungan terhadap mesin- pembangkit dan sudah merupakan standar operasional prosedur. Maka akibatnya pada hari tersebut menjadi hari yang kelabu bagi masyarakat. Listrik di DKI Jakarta, Banten, dan Sebagian Pulau Jawa yakni kawasan yang dihuni lebih 100 juta penduduk ini padam serentak, berhenti tanpa pemberitahuan sebelumnya. Dampaknya, kepanikan mulai terjadi setelah berjam-jam listrik belum menyala. Bukan hanya pemukiman yang listriknya padam. Gedung-gedung perkantoran dan sarana publik juga berhenti beraktivitas. Transportasi publik seperti Kereta Api Listrik (KRL) dan Mass Rapid Transit (MRT) berhenti mendadak. Penumpang panik, turun dan berjalan di atas rel. Bahkan mereka menelurusi jalur MRT menuju area terbuka.

Ketegangan masyarakat makin memuncak saat tidak bisa berkomunikasi. Bukan hanya sinyal telepon seluler terbatas, tapi sebagian kehabisan baterai sehingga menyulitkan komunikasi dengan keluarga, saudara, rekan, di tengah kegelapan. Pihak PLN memang sudah meminta maaf. juga mengumumkan kerugian sekitar Rp 90 miliar akibat padamnya aliran listrik tersebut. Kerugian PLN sebenarnya tidak seberapa dibandingkan dengan kerugian masyarakat, industri, dan sektor lainnya. Kerugian materil bisa mencapai puluhan triliun, bahkan mungkin ratusan triliun rupiah. Sudah pasti kerugian immateril tidak bisa dihitung. Pada saat tahapan akut ini terjadi, Spekulasi mulai bermunculan, berbagai opini dan keluhan publik bermunculan di media sosial menyebar luas menaruh beban kesalahan pada PLN.

Di bawah tekanan itu, para petugas PLN tidak hanya diam saja menunggu dan pasrah. Para petugas di pembangkit pun sedang berusaha memperbaiki sistem jaringan agar kembali 
beroperasi, namun perbaikan tersebut pun pasti membutuhkan proses. Karena untuk menghidupkan kembali Pembangkit Listrik Tenaga Uap (PLTU) di setiap wilayah jaringan tersebut dibutuhkan waktu yang lama. ada tahapan cold start yang dimana Artinya PLTU yang telah terlalu lama tidak terhubung akan beroperasi lagi dari posisi dingin yang membutuhkan proses operasional setidaknya 8 jam untuk kembali memproduksi uap. Dari uap itu, bisa digerakan untuk turbin yang kemudian diproduksikan menjadi listrik. Mengingat sejak GITET (Gardu Induk Tegangan Extra Tinggi) Suralaya mendapatkan pasokan listrik dari Balaraja yaitu sekitar pukul 17.00 maka dimulai dari waktu tersebut, pasokan listrik sudah mulai menyala secara bertahap. Selanjutnya pukul 03.00 WIB dini hari sudah ada jaringan yang masuk lagi. Sistem sudah dapat stabil dan normal keseluruhan.

Seiring perbaikan teknis di pembangkit dan setiap gardu pun di balik layar terdapat para karyawan PLN yang bekerja untuk mengoordinasikan pemberitaan dan mengklarifikasikan berita-berita miring yang beredar juga menginformasikan info penyebab pemadaman serta ucapan maaf bagi seluruh masyarakat yang terkena kerugiannya.

\section{Tahap Kronik}

Pada tahap ini, dianggap badai telah berlalu yang disusul dengan langkah pembersihan, yang ditandai dengan berubahnya sistem atau struktur bahkan mengubah kebijakan. Pada krisis ini, Tahap kronik terjadi keesokan harinya pada tanggal 05 Agustus 2019, hal ini ditandai dengan pulihnya sistem jaringan secara menyeluruh, namun masih diadakan pemeliharaan, yakni dilakukan dengan cara pemadaman bergilir yang diinformasikan terlebih dahulu yakni masing-masing tiga jam di setiap daerah.

Selain hal tersebut, di tahapan kronik ini masih muncul coverage dan exposure pemberitaan secara menyeluruh mengenai krisis karena Presiden turun tangan langsung mendatangi kantor pusat PLN di Jakarta. Ditambah pula tuntutan masyarakat untuk penggantian direksi serta ganti rugi pemadaman. Pada tahapan ini beredar pula spekulasi negatif mengenai pemotongan gaji karyawan untuk mengganti rugi seluruh masyarakat yang terkena dampaknya. Pada tahapan ini, perusahaan memang masih mendapatkan tudingan dan tuntutan dari banyak pihak, namun secara keseluruhan sebenarnya penyebab dari krisis telah teratasi. Hal-hal yang dilalui ini wajar merupakan efek dari krisis serta proses menuju fase resolusi atau pemulihan citra, bila diiringi dengan strategi yang tepat maka akan cepat. Secara teknis, pada tahapan ini, Sripeni sebagai Dirut plt PLN menyatakan agar masalah itu tidak terulang kembali diperlukan tambahan jaringan di Utara dan Selatan masing-masing sebesar $500 \mathrm{Kv}$. Tujuannya, supaya ada cadangan jika salah satu sirkuit mengalami gangguan teknis seperti yang terjadi kemarin. Hal tersebut pun telah masuk dalam Rencana Usaha Penyediaan Tenaga Listrik PLN 2019-2018 dan Rencana Kerja Pemerintah 2019-2024. 


\section{Tahap Resolusi}

Merupakan pengembalian kondisi perusahaan yang harus tetap diwaspadai karena krisis dapat saja kembali ke tahap prodomal, maka perlu dirumuskan strategi pemulihan untuk mencegah adanya krisis kembali. Pada tahap ini pengembalian citra merupakan fokus utama, karena citra perusahaan di mata publik sudah memburuk dan juga kepercayaan publik terhadap perusahaan telah berkurang, maka dari itu perusahaan mulai melakukan strategi pembenahan dibarengi dengan peran kerja Public Relations.

Perusahaan juga menghadapi hal-hal yang terkait dengan hukum, media, tekanan publik, dan litigasi. Tetapi hikmah yang dapat diambil yaitu perusahaan dapat melihat bagaimana suatu krisis akan timbul, bagai- mana menghadapi krisis, dan memastikan agar krisis serupa tidak terjadi kembali. Selain berupaya dalam pemulihan pemberitaan pada tahapan ini juga PLN mengalami tuntutan kompensasi dari berbagai pihak. Untuk lebih lanjutnya penjelasan mengenai strategi yang dilakukan oleh PLN dalam tahap pemulihan citra akan diulas dalam poin selanjutnya yakni implementasi strategi manajemen krisis Humas PLN UID Jabar dalam menangani isu blackout. Krisis yang dialami oleh PT. PLN (Persero) merupakan krisis yang cukup besar karena melibatkan sebagian wilayah di Pulau Jawa. Krisis ini diakibatkan oleh kesalahan industri yakni lumpuhnya jaringan distribusi di Wilayah Utara yakni Saluran Udara Tegangan Ekstra Tinggi (SUTET) di Wilayah Ungaran-Pemalang pada Tanggal 04 Agustus 2019 Silam. Hal inilah yang menyebabkan terjadinya pemadaman serentak (blackout) di DKI Jakarta, Banten, sebagian Jawa Barat, dan sebagian Jawa Tengah.

Selain upaya perusahaan untuk memperbaiki masalah teknis, masih banyak aspek lain yang perlu juga untuk dipikirkan, yakni pelanggan yang mana pelanggan merupakan komponen utama dari perusahaan jasa kelistrikan pelat merah ini. Maka dari itu, selain masalah teknis yang harus dipulihkan, citra perusahaan dan kepercayaan publik pun perlu dikembalikan melalui strategi komunikasi. Strategi komunikasi krisis atau biasa disebut manajemen krisis ini ada di bawah naungan kerja public relations yakni tugasnya sebagai jembatan antara perusahaan menjalin hubungan dengan publik baik internal maupun eksternal. Public Relations inilah yang menjadi garda terdepan perusahaan pada setiap hal. Dalam kasus ini, Public Relations harus pula memulihkan situasi tidak hanya di dalam perusahaan namun publik yang tengah dilanda kepanikan, dan riuh spekulasi serta anarki.

Dalam menangani krisis ini, PT.PLN membentuk suatu Tim yang terdiri dari Pimpinan di Pusat yakni Dirut plt PLN, Corporate Communications, serta tim komunikasi di berbagai area. Untuk melaksanakan manajemen krisis tersebut, para karyawan tidak hanya langsung melaksanakan tindakannya, namun di balik itu segala strategi telah dipikirkan baik buruk serta pro kontranya. Public relations dalam menjalankan manajemen krisisnya pun memerlukan sebuah identifikasi terlebih dahulu mengenai apa itu krisis, sehingga mengenal krisis secara mendalam akan menciptakan strategi di waktu yang tepat. Tahap Analisa Krisis melalui empat tahapan, yakni Tahap Prodomal, Tahap Akut, Tahap Kronik, dan Tahap Resolusi. Setiap tahapan tersebut memiliki cara penanganannya yang berbeda, karena apabila 
salah strategi akan menimbulkan efek yang cukup fatal yakni kesalahan persepsi publik. Strategi yang dilakukan pun mengacu kepada teori manajemen krisis dari Steven Fink yang dikemukakan oleh Rhenald Kasali, yakni lima bentuk rangkaian strategi sebagai tindakan dari awal terjadinya krisis hingga krisis mereda. Lima strategi ini meliputi Identifikasi Krisis, Analisa krisis, Isolasi krisis, Strategi Pemulihan, dan Program pengendali.

Tindakan dari tim manajemen krisis meliputi bagaimana cara memangani serangan pertanyaan dari media, tutur bersikap dan pemilihan diksi untuk menjawab, bagaimana meredam keluhan pelanggan di sosial media, hingga tahapan peredaan krisis dengan membentuk program kebijakan baru yang dapat menjadi titik balik menuju kesuksesan dan pencapaian baru yang dialami setelah krisis terjadi.

Berdasarkan hal ini dapat dinyatakan bahwa strategi manajemen krisis PLN menekankan proses strategi adaptif dengan melakukan modifikasi operasional, kompromi dan pengalihan fasilitas yang tertuang dalam program kerja humas, sehingga strategi yang direalisasikan dalam menghadapi situasi krisis dirasa cukup efektif. Pelanggan tetaplah loyal terhadap produk PLN dikarenakan PLN tetaplah menjadi perusahaan penyedia jasa listrik terbesar di negara ini, walaupun demikian perusahaan mengalami kerugian sebesar 90 milyar pada saat terjadi krisis dan juga kerugian proses hukum dalam bentuk kompensasi kepada masyarakat yang terdampak pemadaman. Namun, dengan berbagai macam strategi manajemen krisis tersebut juga dengan upaya PLN untuk terus berinovasi dengan menciptakan produk layanan baru dan terus meningkatkan kualitas pelayanannya maka dampak dari krisis tersebut akan segera memulih dan perusahaan kelistrikan pelat merah ini pun akan terus berjaya berupaya menerangi seluruh Nusantara.

\section{Implementasi Strategi Manajemen Krisis Humas PLN UID Jabar dalam Menangani Issue Blackout}

Dari hasil pengamatan dan observasi penulis ini menemukan bahwa krisis yang terjadi pada PT. PLN Persero ini disebabkan oleh kesalahan teknis yakni dampak dari terganggunya sistem jaringan di Saluran Tegangan Ekstra Tinggi 500 Kv Ungaran-Pemalang. Proses krisis terjadi pada Ahad, 04 Agustus 2019 pukul 11.47 WIB Hingga Senin, 05 Agustus 2019 dini hari. Akibatnya ialah lumpuhnya sistem kelistrikan DKI Jakarta, Banten, dan Sebagian Provinsi Jawa Barat dan Jawa Tengah. Fenomena blackout ini terjadi di kisaran 612 jam.

Maka dari hal itu, dibentuk adanya suatu tim komunikasi krisis internal yakni dari tim jajaran direksi serta corporate communication PLN Pusat yang menjadi pimpinan manajemen krisis dan tim krisis eksternal yakni investigator yang berasal dari kepolisian, perguruan tinggi dan sejumlah ahli ketenagalistrikan, pihak dari PLN, serta BPPT yang mana dalam situasi krisis akan melakukan koordinasi yang dijembatani oleh spokeperson dan tim humas untuk menentukan strategi yang tertuang dalam program atau kebijakan sesuai dengan analisis situasi. Manajemen krisis merupakan pendekatan terstruktur dalam penanganan suatu 
peristiwa, tujuanya untuk memberikan strategi komunikasi yang tepat sehingga informasi yang disampaikan kepada khalayak dapat diterima dengan cepat dan membantu mengurangi resiko atau kerugian.

Terbentuknya suatu manajemen krisis bagi tim krisis yang dikomando oleh pimpinan pusat tidak terlepas pada tahapan krisis itu sendiri, hal tersebut berkaitan karena strategi yang tertuang dalam program melalui Analisa tahapan krisis yang telah dipaparkan, humas dapat menentukan manajemen krisis secara efektif dan efisien, seperti halnya konsep Steven Fink menjadi pertimbangan humas untuk membentuk proses manajemen krisis yang dikemukakan oleh Rhenald Kasali sebagai berikut:

\section{a) Identifikasi Krisis}

Humas pada langkah ini mulai melakukan pembacaan situasi atas penyebab terjadinya krisis, dengan melakukan koordinasi dan konfirmasi terkait penyebab krisis dengan meminta kepastian berupa data dan fakta yang terjadi di lapangan kepada seluruh unit.

\section{b) Analisa Krisis}

Pada tahap analisa krisis ini PLN beserta pimpinan telah dengan mantap mengetahui lokasi titik kerusakan serta menginformasikan berapa lama pemulihan sistem akan berlangsung. Saat ini PT PLN Persero sedang menyiapkan bahan klarifikasi untuk press conference di mana pimpinan berperan sebagai spokeperson. Pada tahap Analisa ini juga selanjutnya dipersiapkan berbagai strategi lanjutan untuk dapat mengatasi tekanan dari spekulasi dan berbagai macam tudingan publik. Karena di saat Analisa krisis pun berlangsung PLN juga telah dikenai keluhan di lini media sosial.

\section{c) Isolasi Krisis}

Isolasi sebuah krisis dilakukan pada tahapan akut. Tahapan ini krisis telah tercium oleh publik dan media sudah mulai memberitakan peristiwa yang sedang terjadi, untuk itu perusahaan pada tahapan ini sudah melakukan pergerakan dengan mengeluarkan dokumen atau modul sebagai panduan perusahaan menangani krisis ini.

Berdasarkan hasil temuan humas PT. PLN Persero telah melaksanakan prosedur Isolasi krisis dengan cukup baik. Dengan cara memilih milah informasi yang disampaikan kepada publik di tengah tekanan publik dan media meminta keterangan lebih lanjut mengenai fenomena blackout dan pertanggungjawabannya ini. Hal yang paling mendasar yang dibentuk oleh tim manajemen krisis ialah membentuk sebuah Grup di aplikasi whatsapp sebagai wadah koordinasi komunikasi krisis. Dimana dalam grup tersebut dilakukan penyelarasan informasi dari pimpinan pusat hingga ke masing-masing area. Cara bersikap dan menjawab pimpinan di hadapan media pun 
berpengaruh. Sikap prihatin dan rendah hati yang ditujukan dengan tutur kata santun hingga raut senyum tulus dapat mempengaruhi cara pandang publik.

Tahapan isolasi krisis inipun seiringan dengan proses investigasi yang dilakukan oleh kepolisian, ahli ketenagalistrikan, dan juga pihak PLN. Sehingga memang benar adanya untuk mengetahui runtutan jawaban yang pasti harus menunggu tim.

\section{Strategi Pemulihan}

Dalam strategi pemulihan ini. PT. PLN Persero menggunakan strategi adaptif untuk memulihkan situasi krisis. yang merupakan cara untuk memulihkan kembali keadaan dengan mengubah kebijakan, memodifikasi operasional, kompromi dan meluruskan citra.

Contoh nyata dari strategi adaptif yang dilakukan oleh Humas PLN ialah saat warga sukabumi akan mengadakan Demo untuk PLN, Pimpinan Manajer Bidang Komunikasi PLN Jabar beserta staffnya segera bertandang ke Sukabumi untuk melakukan engagement serta negosiasi. Warga diberikan penjabaran secara ramah dan mendalam agar dirasa PLN bertanggungjawab atas hal yang demikian. Beruntungnya aksi demo dapat diurungkan.

Semenjak krisis berlangsung, pada saat monitoring media cetak maupun online. Hasil yang ditunjukkan oleh keseluruhan media pun mayoritas $90 \%$ berita dengan tonalitas negatif. Hal ini akan sangat berdampak kepada cara pandang masyarakat terhadap perusahaan. Maka dari itu untuk meningkatkan kembali pemberitaan positif, pimpinan mengarahkan agar Humas di tiap wilayah beriklan berita positif di media tier agar perusahaan mendapati kembali publik dengan cara pandang yang positif. Berkenaan dengan momen Idul Adha, PLN pun beriklan berita tentang bagaimana PLN menjaga pasokan listrik saat Idul Adha. PLN Juga tidak lepas dari tanggung jawab, di tengah pemberitaan negative dan upaya pemulihan citra, PLN pun masih dibayangi oleh proses hukum mengenai kompensasi dampak dari blackout. strategi yang tepat digunakan ialah bagaimana PLN tidak mangkir dan pada media pun menyatakan sedang dalam perhitungan kebijakan dana kompensasi tiap warga.

\section{Program Pengendali}

Program ini dikatakan sebagai langkah penerapan pasca terjadinya krisis merupakan suatu upaya pengendalian, dengan harapan daur hidup krisis tidak terjadi lagi. Walaupun memang krisis sudah terjadi, dan dampaknya sudah terasa namun setidaknya PT.PLN dapat lebih tanggap dan melakukan sesuatu. Program pengendali bertujuan untuk menerapkan kebijakan pasca krisis program pengendali ini merupakan kegiatan pengendalian dengan pemantauan dan koordinasi berkelanjutan.

Langkah nyata yang dilakukan oleh PLN ialah dengan membahas program baru serta menuntaskan apa-apa yang belum terselesaikan. Seperti contohnya ialah PLN meluncurkan iklan yang berisikan promo di koran. Mengenai potongan harga bagi tambah daya dan penyambungan sementara. Selain itu juga PLN sibuk dengan mengurus penyelesaian 
kompensasi bagi setiap pelanggan. Kompensasi ini sendiri telah tersedia kebijakannya sesuai peraturan Menteri yakni Untuk pelanggan pasca bayar PLN bersubsidi akan mendapatkan 20 persen potongan, dan 35 persen potongan biaya beban untuk pelanggan non subsidi pada pembayaran listrik bulan September mendatang. Sementara, untuk pelanggan prabayar akan mendapatkan dua token ketika mereka membeli token baru ditambah token kompensasi dari PLN. Sehingga pelanggan tidak perlu repot untuk mendaftar, semuanya telah tercatat by sistem. Jika dirupiahkan kompensasi untuk wilayah jawa barat kira-kira 30 persen dari total dampak secara nasional, di Jabar berkisar nilai Rp 330 miliar.

Perusahaan PLN Juga sempat disoroti oleh media dalam acara talkshow off air Jawa Barat Punya Informasi (JAPRI) yakni merupakan program Pemprov secara rutin yang diadakan di Gedung Pemerintahan Provinsi Jawa Barat (Gedung Sate). Pada tema talkshow tersebut dituliskan ialah mengenai Elektrifikasi Jawa Barat. Talkshow tersebut dihadiri oleh Senior Manajer Bidang General Affairs, Bapak Andhoko Soeyono selaku Narasumber. Sebelum Talkshow itu berlangsung, Tim komunikasi dari PLN Jawa Barat telah menyiapkan strategi jawaban dan bahan pembicaraan selama acara berlangsung. Hal ini ditujukan agar media tidak menyasar out of topic yakni mengincar PLN membahas kasus blackout. Maka dari itu sejak awal acara dimulai narasumber tidak sama sekali menyinggung mengenai blackout, namun lebih diarahkan kepada topik sesuai tema yakni elektrifikasi di Jawa barat serta kompensasi. Fokus pembahasan target kinerja pemenuhan melistriki sisa 0,01\% penduduk di Jawa Barat. Narasumber pun membahas mengenai alur kebijakan kompensasi yang berupa potongan pembayaran. Maka media dan publik teralihkan dan fokus membahas program yang menakjubkan serta fokus kepada kata "diskon"

Selain strategi komunikasi yang kian diterapkan, PLN memang memiliki beberapa program pengendali berupa peluncuran produk baru dan bentuk direct marketing dengan temu pelanggan pada acara car free day di Dago, 25 Agustus 2019 Silam yang mana di kesempatan tersebut merupakan sosialisasi promo dan pengenalan produk Tv kabel serta jaringan wireless terbaru yakni Icon+. Ide berbagai bentuk promo dan momen peluncuran produk baru tidak semata hanya untuk tujuan promosi, namun juga termasuk strategi program pengendali untuk memulihkan citra perusahaan di mata publik dengan munculnya inovasi.

\section{Gambar 1. Sosialisasi Promo di CFD Bandung}

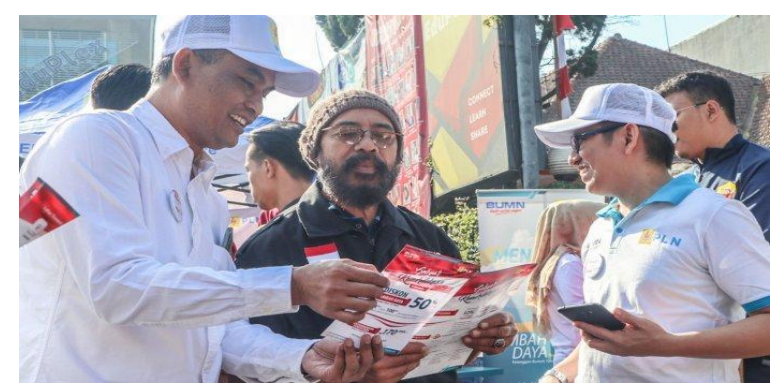




\section{KESIMPULAN}

Krisis yang dialami oleh PT. PLN (Persero) merupakan krisis yang cukup besar karena melibatkan sebagian wilayah di Pulau Jawa. Krisis ini diakibatkan oleh kesalahan industri yakni lumpuhnya jaringan distribusi di Wilayah Utara yakni Saluran Udara Tegangan Ekstra Tinggi (SUTET) di Wilayah Ungaran-Pemalang pada Tanggal 04 Agustus 2019 Silam. Hal inilah yang menyebabkan terjadinya pemadaman serentak (blackout) di DKI Jakarta, Banten, sebagian Jawa Barat, dan sebagian Jawa Tengah.

Dalam menangani krisis ini, PT.PLN membentuk suatu Tim yang terdiri dari Pimpinan di Pusat yakni Dirut plt PLN, Corporate Communications, serta tim komunikasi di berbagai area. Untuk melaksanakan manajemen krisis tersebut, para karyawan tidak hanya langsung melaksanakan tindakannya, namun di balik itu segala strategi telah dipikirkan baik buruk serta pro kontranya. Public relations dalam menjalankan manajemen krisisnya pun memerlukan sebuah identifikasi terlebih dahulu mengenai apa itu krisis, sehingga mengenal krisis secara mendalam akan menciptakan strategi di waktu yang tepat. Tahap Analisa Krisis melalui empat tahapan, yakni Tahap Prodomal, Tahap Akut, Tahap Kronik, dan Tahap Resolusi. Setiap tahapan tersebut memiliki cara penanganannya yang berbeda, karena apabila salah strategi akan menimbulkan efek yang cukup fatal yakni kesalahan persepsi publik. Strategi yang dilakukan pun mengacu kepada teori manajemen krisis dari Steven Fink yang dikemukakan oleh Rhenald Kasali, yakni lima bentuk rangkaian strategi sebagai tindakan dari awal terjadinya krisis hingga krisis mereda. Lima strategi ini meliputi Identifikasi Krisis, Analisa krisis, Isolasi krisis, Strategi Pemulihan, dan Program pengendali.

Tindakan dari tim manajemen krisis meliputi bagaimana cara memangani serangan pertanyaan dari media, tutur bersikap dan pemilihan diksi untuk menjawab, bagaimana meredam keluhan pelanggan di sosial media, hingga tahapan peredaan krisis dengan membentuk program kebijakan baru yang dapat menjadi titik balik menuju kesuksesan dan pencapaian baru yang dialami setelah krisis terjadi. 


\section{DAFTAR PUSTAKA}

Gussman, S. Y., \& Kurniadi, H. (2018). Analisis peran dan fungsi humas dalam manajemen institusi pendidikan. Jurnal Communiverse, 3(2), 76-89.

Koswara, A. (2014). Komunikasi krisis: analisis upaya respon krisis Teluk Meksiko dari perspektif public relations. Jurnal Edutech, 1(1), 107-131.

Muchtar, K. (2016). Komunikasi politik dan pembentukan citra partai. Jurnal Ilmu Komunikasi, 14(2), 136-147.

Negoro, S. H. (2014). Kredibilitas Customer Service dan Citra Perusahaan. Jurnal IlLMU KOMUNIKASI, 11(2), 215-230.

Partao, Z. A. (2005). Optimalisasi fungsi media relations untuk keberhasilan komunikasi krisis. Jurnal Komunikologi, 2(1), 1-14.

Prihatin, G., \& Hidayat, Z. (2011). Hubungan kualitas layanan informasi motto agent dengan citra produk kepada pengguna ponsel motorola. Jurnal Komunikologi, 8(1), 60-78.

Roro, R., Juneza, D., \& Purworini, D. (2016). Respon para disabilitas terhadap komunikasi krisis BPBD (Badan Penanggulangan Bencana Daerah) dan Tim SAR Klaten Tahun 2016. Jurnal Profetik, 10(1), 80-96.

Sucahya, M., \& Surahman, S. (2017). Difusi inovasi program bank sampah. Jurnal Ilmu Komunikasi, 8(1), 63-79.

Suharyanti, \& Sutawidjaya, A. H. (2012). Analisis krisis pada organisasi berdasarkan model anatomi krisis dan perspektif public relations. Journal Communication Spectrum, 2(2), 165185. 